\title{
The Pragmatics of Blackmail in English and Iraqi-Arabic
}

\author{
Zainab Kadim Igaab ${ }^{1}$ \\ ${ }^{1}$ University of Thi-Qar, College of Education for Humanities, Department of English, Iraq \\ Correspondence: Zainab Kadim Igaab, University of Thi-Qar, College of Education for Humanities, Department \\ of English, Iraq. Tel: 00964-7800-045-735. E-mail: zaineb-k@utq.edu.iq
}

Received: September 3, 2021; Accepted: September 17, 2021; Published: September 18, 2021

\begin{abstract}
Verbal offences are language crimes that are committed by mere utterances of certain words or expressions whether they are accompanied by physical acts or not. One of those crimes is blackmail. This crime has been studied and compared legally but its linguistic aspect has not been given much attention. This study tries to emphasize this crime pragmatically and contrastively in English and Arabic. No study has shed light on such aspects concerning the study under investigation. The researcher has not found any previous related study to get a benefit from about this topic. There is an attempt to achieve the following aim which is shedding light on the similarities and differences in strategies of blackmail between English and Arabic in terms of speech act, implicature and impoliteness theories. The present study hypothesizes the following: English and Arabic are different from each other in expressing blackmail in terms of speech act theory, implicature and impoliteness. To support or refute the hypothesis of the study, data consisting of 20 complaints in English and Arabic were collected from Courts of Appeal in Iraq, Britain and the United States. They are analyzed in terms of an eclectic model. The results arrived at are: English and Arabic are different in blackmail in terms of the locutionary acts and illocutionary acts. Concerning impoliteness, the same strategies are applied to the verbal offence in both languages. As far as implicature is concerned, the two languages are different in blackmail.
\end{abstract}

Keywords: pragmatics, blackmail, English, Arabic

\section{Introduction}

The legal field, to which law belongs, constitutes an independent culture with powerful vocational norms that give sense and reinforcement to the individual's behavior. That is why, even a lawyer and client, who belong to the same culture will go through the client-lawyer misunderstanding because of the cultural dissimilarities which result from legal culture (Betti and Hashim, 2018: 277).

It is not always simple to avoid conflicts between the right to free speech and the right to have protection against unwarranted damage to reputation caused by false accusation (Algburi and Igaab, 2021:31). The purpose of speech in a given context is to generate some kind of action. Every sentence is structured to carry certain intention. Intentional human action is the concern of pragmatics. Intentional action is intended to achieve a goal, through some kind of plan, give some beliefs about state of things. This results in "speech acts" that are carried out directly or indirectly. When speaking, all sorts of things can be done, from aspirating a consonant, to constructing a relative clause, to insulting a guest, to starting a war. These are all speech acts. Speech act theory has been one of the basic ingredients of pragmatics for a long time (Betti, Igaab \& Al-Ghizzi, 2018: 253).

Crimes are committed by uttering words or expressions, writing or signifying in a public way like blackmail. It consists of two elements which are physical and internal (actus reus and mens rea). Blackmail is criminalized or not according to different points of view within the countries (Igaab, and Altai, 2018: 289).

Criminalizing blackmail is different from one country into another. So, it is problematic. Blackmail is regarded as a crime of opportunity and exploitation for some (Igaab, and Tarrad, 2019: 61).

\subsection{Research Questions}

What are the similarities and differences in strategies of blackmail between English and Arabic in terms of speech act theory, implicature and impoliteness?

\subsection{Aims of the Study}

The study aims at showing to what extent English and Arabic are different in expressing strategies of blackmail in terms of speech act theory, implicature and impoliteness. 


\subsection{Hypotheses of the Study}

This study hypothesizes the following: English and Arabic are different from each other in expressing strategies of blackmail in terms of speech act theory, implicature and impoliteness.

\subsection{Literature Review}

\subsubsection{The Legal Aspect of Blackmail}

Idiomatically, blackmail is threatening the victim to harm him/her or any person relating to the victim. So, the victim is to be forced to give the blackmailer money, or putting the victim's signature or seal on a legal paper for the blackmailer's benefit (Al-Abdullah, 2013: 17 and Al-Ma'moury, 2006: 370). Radfield (2012: 311-312) defines blackmail as being "a close cousin to robbery. It is the extortion of money by threats rather than by violence."

A person becomes guilty of blackmail if he/she wants to gain for him/ herself or another one or he/she intends to cause loss to another. So, unwarranted demand with menaces is made but that demand will be warranted in terms of two conditions:

a) if a person believes that he has reasonable grounds for making the demand;

b) using the menaces is an appropriate means to reinforce the demand (Elliot and Quinn, 2004: 171 and Mustafa, 1964: 536) while in the Iraqi penal code, there is no clause item which criminalizes such a crime but it is included within other crimes like a threat. Actus Reus of blackmail is a demand with menaces must be available. In mens rea, the defendant has an intention to make the demand with menaces. That demand must be made to make a financial gain or to cause a financial loss (Elliot and Quinn, 2004: 172; and Ubaid, 1985: 428-429).

\subsubsection{The Pragmatic Aspect of Blackmail}

Blackmail is considered an ancient crime but it has adopted itself to modern technology (Wasik, 1990: 22). There is a debate over blackmail prohibition. Lindgren (1984) was faced with a trouble because of what he called the paradox of blackmail. He explained it in the following way: to threaten a person to expose a criminal act unless he is paid money is committing blackmail, or to threaten to expose a sexual affair unless he is given a job is also committing blackmail (Al-Seady, and Al-Sehlani, 2002: 40). It is a legal right to expose or threaten to expose the crime or affair, and it is a legal right to be paid money or given a job but the combination of both rights is blackmail. So, if exposing or threatening to expose is legal and seeking money or a job is also legal but their combination is illegal. This is what is called the paradox of blackmail (Dripps, 2009: 249; Fitzpatrick, 1998:38 and Katz, 1996: 133; Igaab, 2010: 28).

Blackmailers threaten the victims' lives or threaten to burn their houses or to accuse any person of an infamous crime, with intent to extort or gain money (Ginsburg and Schechtman, 2016: 1851-1852).

In English, although the debate over blackmail prohibition is still held with the existence of two opposite viewpoints, blackmail should be prohibited because it is regarded as a type of exploitation (Igaab, and Kareem, 2018: 99). It is blameworthy; it is accompanied with malicious motivation; it is bad for the merchants in their business; exposing the information embarrasses the victim; it does not affect the reputation but also the interests and privacy. So, it is totally refused by the Iraqi-Arabic community without tending to find more than one point of view about its prohibition. The blackmailer threatens the victim to reveal some information which is not his, it belongs to the society or to the blackmail victim (Igaab, 2015: 54).

Blackmail is better to be described as an unproductive and involuntary exchange. It is considered as an incentive for invasion of privacy. Everyone has their privacy away from prying eyes (Rosenberg, 2008: 357-358 and Katz, 1996: 141; Al-Seady, 2002b: 13).

\subsubsection{Speech Act of Blackmailing}

Language is a powerful means of human communication. Via using language, the sender can deliver his/her intended meaning to the receiver. According to Grice, the communicative activity should go smoothly and straightforwardly. Thus, Grice postulates the cooperative principle in that people should be cooperative in their communication (Betti and Yaseen, 2020: 43)

The theory of speech acts is, no doubt, one of the main theories in pragmatics. It is originated in the ideas of J. L. Austin expressed in the series of his lectures "How to Do Things with Words" and then developed by Searle's (1975) and others. Austin's basic idea behind his theory of SAs is that utterances (Us) do not only bear meaning, but rather they do things, i.e., perform actions (Levinson, 2017, p. 199; Al-Sheikh, (2006a: 75). In Austin's words, "to say something is to do something" (1962). To perform a SA is "an attempt at doing something purely by speaking" (Trask, 1999, p. 189). Yule (1996: 47) defines SAs as "actions performed via utterances (Betti and 
Hasan, 2020: 43). Birner (2013: 192) elaborates on this as "imperatives canonically have the illocutionary force of a command (or, relatedly a request, invitation, suggestion, etc.- essentially milder forms of a scale ranging from "suggestion" to a "command")". But, in the case of indirect speech act there is no correspondence between the linguistic form and the illocutionary force of the sentence; for example, to have a request in the form of interrogative or declarative (Betti and Hashim, 2021: 34).

Blackmail as a crime is both illocutionary and perlocutionary acts. It is an act of blackmailing, harming the victim by forcing him/her to pay an amount of money; to do something; or not to do something in order not to reveal his personal secrets or his family members'. The effect is paying money unwillingly. The blackmailer does not care whether that person can or cannot pay. The victim is forced to do anything to defend his reputation (Juris, 1988: 83-84).

With this crime, the victim will not behave freely and he will be coerced to pay money to make his secrets or private information be kept. In this way, blackmailers are described as being entrepreneurs who find a way to make money. It is like a process of pointing a gun towards the victim to get money. So, blackmail is similar to physical coercion (Juettner, 2009: 18; Igaab, and Abdulhasan, 2018: 90).

\section{Methodology of the Study}

\subsection{Research Design}

To achieve the aim of the study and test its hypothesis, the following steps will be followed:

1. writing the literature review of blackmail from legal and pragmatic aspects;

2. analyzing the English and Arabic data according to an eclectic model;

3. discussing the data whether English or Arabic;

4. writing the examples in the Arabic section follows two steps which are: a) translating the examples into English and b) transliterating it.

5. arriving at a number of general conclusions with showing the similarities and differences between

English and Arabic in terms of blackmail.

\subsection{Data Collection}

The data of this study are a number of complaints of blackmail. The complaints are 20 in number. The English data are taken from Juettner (2009) for blackmail cases and the English website: https://www.govinfo.gov/ while the Arabic data are taken from judges of investigation in Nasiriya Court of Appeal and investigators in the police centre in Thi-Qar Province. The translation of the pragmatic and forensic linguistic terms into Arabic is taken from Ritchard, et al. (2007). Longman Dictionary of Language Teaching \& Applied Linguistics: EnglishEnglish- Arabic and Yousif (2020). "Conversational Maxims in Pragmatics".

\subsection{The Model}

The model of the study is eclectic, i.e., it is taken from Grice (1967), Searle (1975) and Culpeper $(1996,2005)$. Following the model, English and Iraqi-Arabic cases will be analysed. Implicature and impoliteness are the same in both languages while speech act theory is different from English into Arabic (Al-Seady, 2002a: 34). With Speech act theory in Arabic, there are different points of view and opinions presented by Arab linguists, grammarians, and rhetoricians. But they agreed on the distinction made among locutionary, illocutionary and perlocutionary acts. So, cases of both languages will be analysed following the same model by Searle (1975) and Betti, and Igaab, 2018: 37).

\subsubsection{Background}

In this eclectic model, there is a background for every case. It includes a speech event and the problem of every case.

\subsubsection{Implicature}

In 1967, Grice first presented his theory of implicature. That was a shorter version of what was published in 1975 in a paper "Logic and Conversation". Related to implicature, he came with the cooperative principle and its related maxims.

In his theory, he tried to elucidate how the hearer gets from what is said to what is meant; from the level of the expressed meaning to the level of the implied meaning (Al- Sharify and Al-Shimary, 2017: 421; Liedtke, 2011: 53-54; Ismail, 2005: 13, 78; Thomas, 1995: 56 and Grice, 1975: 43-44).

For people to use ironic expressions, they must say something a nd imply another and this depends on the common 
awareness of the English usage by the speaker and the hearer (Allan, 1989: 4-5; and Betti and Khalaf, 2021: 20). Irony is generated by breaking Grice's maxims intentionally to communicate something (Black, 2006: 25). Implicature arises from the use of irony as it requires an implication for it to utter (Al-Sheikh, 2006b: 71).

\subsubsection{Impoliteness}

A great attention has been paid to politeness and a little attention to impoliteness. Impoliteness which is described as being a poor cousin of politeness has been neglected (Locher and Bousfield, 2008: 1-2 and Bousfield, 2008a: 71).

There is agreement on that politeness and impoliteness can be discussed together but no solid agreement exists on what impoliteness actually is. But they agree on a definition which is impoliteness as a behaviour that is face aggravating in a particular context. Such a definition is finally not enough and most researchers have suggested more elaborate definitions. According to Bousfield, impoliteness is defined as constituting the issuing of intentionally gratuitous and conflictive face threatening acts which are achieved on a purpose. To Culpeper, it is a communicative behaviour which intends to cause the "face loss" of a target or noticed by the target to be so. To Terkourafi, it happens when the expression which is used is not conventionalized related to the context of occurrence, there is a threat of the addressee's face (and through the speaker's face) but there is no face-threatening intention which is done to the speaker by the hearer (Al-Seady, 1998c: 79).

According to Bousfield and Culpeper, understanding the speaker's intentions by the hearer is the key for impoliteness while to Terkourafi, it is the rudeness rather than impoliteness. The fourth definition was presented by Locher and Watts. It is a negatively marked behaviour which has violated the social norms (Culpeper, 2011: 19-20). The result is negative evaluations like 'impolite, over-polite, rude, aggressive, insulting, sarcastic, etc', relying on the degree of the violation and the kind of conceptualization (Locher and Bousfield, 2008: 3-4).

Non- politic, inappropriate, and marked are the defining features of impoliteness. To watts, if the speaker intends to hurt the hearer's feelings, this is done via language. If the politic behaviour is missing, so that behaviour is described as being impolite, brash, inconsiderate, abrupt, rude. Locher and Watts define impoliteness as breaches of norms that are negatively evaluated by participants. Participants should share the same norms whether experiential or social to get rid of any difficulty in the interaction. With impoliteness, an offence is intentionally caused (rational management) and it is an intentional face-attack (Culpeper, 2008: 28, 30, 32). Increased indirectness may lead to increased impoliteness (Terkourafi, 2008: 46).

Face constitution or threatening are used as perlocutionary effects which depend on the recognition of the speaker's intention. For example, a shopper allows the others to pass. She does not intend to be polite but her behaviour was evaluated as polite and the evidence was thanking her for her behaviour (ibid: 58).

Impoliteness is a type of the perlocutionary effect. It includes the hearer thinking that the speaker is approaching/ withdrawing inappropriately given cultural norms whether this involves omitting an appropriate move or adding an inappropriate one. The effect of constituting face is a threat to face. Impoliteness is distinguished by being a face-threatening perlocutionary effect (Terkourafi, 2008: 60, 62).

Culpeper (1996) defined impoliteness as "the use of strategies designed to attack face, and thereby cause social conflict and disharmony." Then in 2005, Culpeper refined this definition into the following:

Impoliteness comes about when : (i) the speaker communicates face-attack intentionally, or (2) the hearer perceives and / or constructs behaviour as intentionally face-attacking, or a combination of (1) and (2).

In 2005, Culpeper suggested and developed a model where there is a shift in the focus of intentional, impolite faceattack away from a Brown and Levinson style 5- point model of offensive super-strategies. That model was proposed by Lachenicht (1983) and Culpeper (1996) and followed by others. The super-strategies are:

(1) Bald, on Record Impoliteness

The speaker intends to attack the face of the hearer and / or where the speaker does not have the power to (safely) say an impolite utterance. The utterance is expressed directly, clearly, and unambiguously (in a full way in accordance with Grice's maxims (1975)). For example, the use of taboo words (Hashim, and Betti, 2020: 299).

\section{(2) Positive Impoliteness}

It is the attacking of the hearer's want to be approved of , which is clearly linked with Spencer-Oatey's (2002) quality face and elements of sociality face. It involves strategies used to damage the recipient's positive face wants. Instances of those strategies are 'ignore, snub the other, exclude the other from the activity, dissociate from the other, be disinterested, unconcerned, unsympathetic, use of inappropriate identity markers, use obscure or secretive language, seek disagreement, make the other feel uncomfortable, for example, do not avoid silence, joke, or use 
small talk, use taboo words, call the other names, etc.' for example, 'shut up' which is regarded as an obstacle of speech (Igaab, 2010a: 22).

(3) Negative Impoliteness

Culpeper makes a link between attacking your freedom of action and Spencer- Oatey's (2002) equity rights and then with association rights. It involves the use of strategies which damage the recipient's negative face wants. The examples of those strategies taken from Culpeper (1996) are 'frighten, condescend, scorn, or ridicule, invade the other's space, explicitly associate the other with a negative aspect, put the other's indebtedness on record, etc.' (Igaab and Al-Manhalawey, 2010: 43).

(4) Off- Record Impoliteness

This super-strategy was introduced by Culpeper (2005) instead of the 'meta-strategic' nature of sarcasm. Here, the offence can be conveyed in a direct way in terms of implicature that could be cancelled. For example, threatening someone of beating him (Igaab, and Al-Bdeary, 2016: 43).

(5) Withhold Politeness

With the absence of politeness, impoliteness may exist. For example, a person does not thank the other for giving him a present.

Such a model has been re-explained since there is a problem with a bold, on record strategy because it is not found outside of the theorist's vacuum (Culpeper, 2013: 5; Bousfield, 2008a: 127-139 and Bousfield, 2008b: 72- 96).

\subsubsection{Identifying Speech Acts}

Language is not only used to say things (to make statements) but also to do things (perform actions). Such a conviction pushed J. L. Austin to make a theory of what he called "illocutionary acts", "speech acts", "illocutionary force", "pragmatic force", or "force". Things are done by words (Betti and Mahdi, 2020: 69). There are no statements or questions but there are utterances with performative verbs to do actions:

I declare the meeting open. (Rühlemann, 2019: 16; Khudhair, 2017: 120-123; Adrawy, 2011: 73; Abu-Zaid, 2009: 26-30; Boqra, 2009: 186; Proost, 2006: 994; Achiba, 2003: 1-2; Grundy, 2000: 48-50 and Thomas, 1995: 28-36).

Speech act theory was first put forth by Austin $(1962)$ and further developed by Searle $(1969,1979)$. This theory is based on two major ideas. The first is that the meaning of an utterance is distinct from the function performed by that utterance which is called the force; and the second is that all utterances amount to the execution of an act (Collavin, 2011: 373 and Betti and Mahdi, 2021: 17).

Austin made a three-fold distinction among utterances: locution, illocution, and perlocution. Locution refers to the actual words uttered; illocution indicates the force or intention beyond the words; and perlocution means the effect of the illocution on the hearer. For example,

It's hot in here. (locution)

I want some fresh air. (illocution) (Igaab, 2015a: 142).

Someone might open the window. (perlocution) (Rühlemann, 2019: 18; Khudhair, 2017: 124-126; Gharbiya and Shalway, 2010: 45-47; Mey, 2004: 95-97; Grundy, 2000: 50-51 and Thomas, 1995: 49-50).

Searle classified speech acts into direct and indirect. With direct speech acts, there is a direct relationship between the linguistic structure and the work they are doing (Al-Seady, 1998a: 83). For example, a sentence is declarative in form and a statement in function; interrogative and question; imperative and command. With indirect speech acts, there is a mismatch between the linguistic form and the illocutionary force (Igaab, 2010b: 153).

I'd be jolly grateful if you could pull me out, sir. (The form is declarative and the function is a request) (Rühlemann, 2019: 23; Bolkhtot, 2018: 111-113; Birner, 2013: 192; Mey, 2004: 111-113; Peccei, 1999: 55 and Geis, 1995: 122-124). In this way, how can the hearers know what the real illocutionary force is when it exists in an indirect speech act? Here, the benefit of the felicity conditions comes (Dehham, Betti, and Hussein, 2021: 12). An example of a direct speech act:

Please, close the door.

An example of an indirect speech act:

It might help to close the door. (McAllister, 2015: 29; and Igaab, 2015b: 22). 


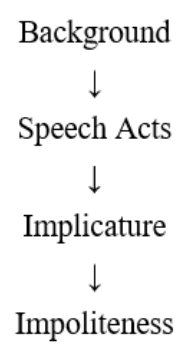

Figure 1. An Eclectic Model for Analysing Blackmail

\section{English Data: Analysis and Discussion}

Ten cases are under an analysis according to an eclectic model. This model consists of the background, speech acts, implicature and impoliteness.

\section{1. a. Background}

In 2008, a British bank revealed that it had paid nine million Euros (about $\$ 13.11$ million) to a former employee, and his accomplice since 2003. That employee had threatened to publish secret documents about the accounts of some of the bank's German clients if the bank did not give him millions of Euros.

\section{b. Speech acts}

The two verbs "threaten and publish" are illocutionary verbs. The bank officials cannot phone the police because they fear that if they expose this former employee's actions to the police, he may immediately release the sensitive information about the bank's clients and officials. This is the perlocutionary effect (Al-Seady, 1998b: 64)..

A former employee threaten the bank officials "I'll publish secret documents about the accounts of some of your clients if you do not pay me what I want."

\section{2. a. Background}

In 2003, Vigan, the burglar, broke into a yacht which was possessed by a British cricket player. Vigan thought that there might be some money and valuable objects to sell but he found videotapes of that player and his wife in bed together. Vigan wrote to the player saying that he had them. He told the player that he would not publish the video on the Internet if the player paid him.

\section{b. Speech acts}

"Had and publish" are illocutionary acts with a perlocutionary act which is the player is forced to pay Vigan what he wants to stop him publishing that video. Something is horrible when that video is exposed to people. It negatively affects the player's honour, reputation, and future. Vigan does not intend to harm the victims or damage their reputation but to enrich himself .

Vigan phoned the player, "I do not intend to embarrass you about what I saw in the videotapes. Pay me first and I'll give them back to you, or I'll publish them."

\section{3. a. Background}

In 2008, Hogan was a consultant for the Utah Telecommunications Open Infrastructure Agency, a state agency which charged with upgrading high-speed internet access. That agency tried to terminate Hogan's job. So, he threatened them by revealing a conflict of interest in contract awards.

\section{b. Speech acts}

"Threaten and reveal" are illocutionary verbs. Exposing such a conflict has a negative effect on the agency fame and work in the world.

Hogan claimed "I was fired for revealing a conflict of interest in contract awards. So, I'll sue the agency for wrongful termination." 


\section{4. a. Background}

Timothy Wright was in a physical relationship with a female staff member at Crossroads. When an inmate knew about that relationship, he attempted to blackmail the female staff member by threatening her to tell other members of the staff and the head.

\section{b. Speech acts}

Telling others about such a physical relationship means a spiritual damage for that female by losing others' confidence in her work.

The inmate said, "Do what I want otherwise I'll make your relationship with that man public. I want you to understand. I am threatening you."

\section{5. a. Background}

Annoyed hackers attacked companies by threatening them to post defamatory material if they did not pay them money.

\section{b. Speech acts}

Those hackers know their legal position and how to protect themselves from any legal liability. Those companies realize that it is cheaper to pay $\$ 2.000$ to the blackmailer instead of legal fees of $\$ 5.000$, particularly when they are unwilling to admit that they were being blackmailed.

Hackers emailed companies, "Many clients are not told specifically that their pages will be changed to being libelous. So, do it. I'm threatening you to post certain defamatory material."

\section{6. a. Background}

In a case of computer eavesdropping, the official netted the blackmailer $\$ 350.000$ because the latter threatened the official to reveal certain financial transactions to the tax authorities.

\section{b. Speech acts}

Exposing those transactions to the tax authorities willmake that official lose his job in the government.

The blackmailer said, "I know about your financial transactions. What do you think of the tax authorities. I'll reveal them to the authorities."

\section{7. a. Background}

In 2009, Stephen's vehicle that was being driven by his son, was pulled over to an area near the police centre. When the officers achieved a "live stop" impoundment of the car, they found cocaine in the car cover. On the pretext of violation of proper procedure like valid registration, the officers arrested the son for "well over an hour" and eventually left him in a hostile area over thirty- five miles from home and without access to public transportation.

\section{b. Speech Acts}

"You want to come back home peacefully, give us \$22.000". After threatening the son to expose what they saw in the car, he gave them that amount of money, otherwise he would be imprisoned.

\section{8. a. Background}

Jacob Hagopian, Senior US Magistrate Judge alleged that defendants like various ACI wardens, supervisors, correctional officers, and medical personnel, had subjected him to psychological warfare with the use of electronic surveillance which was concealed within the light fixture of the cells where he lived. Such devices were used to secretly watch him perform bodily functions and write legal work.

\section{b. Speech Acts}

Then he alleged, "Defendants harassed me by talking about what I did in my cell and trying to blackmail me to stop pursuing my legal claims."

\section{9. a. Background}

Two police officers discussed the chances of them dropping a charge against the defendant in return for payment.

\section{b. Speech Acts}

They did this in circumstances where the defendant could easily overhear them and they meant him to hear them. The use of the verb "dropping" was to blackmail the victim to pay for them. 
One of the police officers talked to the other officer, "I'm ready to drop a charge against that prisoner if he gives something valuable to us."

\section{0. a. Background}

Mr. Man, an investigative journalist, and his team were accused of operating a blackmailing network. Mr. Man was the president of one of the press groups which published several investigative newspapers and weekly magazines which targeted high-level corruption.

\section{b. Speech Acts}

They threatened to disclose compromising information about local politicians and businessmen unless they bought advertising space from the newspapers belonging to their press group.

Mr. Man commented, "It is the only thing that we want from those politicians and businessmen is to buy advertising space or I'll disclose compromising information about them."

\section{c. Implicature}

In the blackmail cases, there is no implicature.

\section{d. Impoliteness}

Studying the use of impoliteness is so important in any communication which is not cooperative but hostile. In this study, impoliteness framework is based on Culpeper's $(1996,2005)$ which followed Brown and levinson's model of politeness (Mohammed and Abbas, 2015).

1. The former employee in the British bank uses a direct, clear and unambiguous threat with the bank. Then he tries to frighten the bank by publishing information which cannot be exposed because it will disbenefit the interests of the bank. Two strategies of impoliteness are used, which are bald on record and negative impoliteness.

2. Vigan told the player directly that he has videotapes in which there is a scandal if they are published. The player is forced to pay him what he wants because the former is horrified. Bald on record and negative impoliteness are also utilized.

3. Because the agency attempts to make Hogan lose his job, he makes them feel scared since he intends to expose some documents which affect their work negatively. So, the first and third strategies of impoliteness are utilized in this case.

4. Without hesitation or behaving secretly, the inmate went to that lady to tell her face to face that her relationship with Wright was known by him. So, she has to fulfill something for him in the work otherwise he would tell everybody of the staff about that secret relationship. She felt feared since such a behaviour would destroy her life. Like other cases, bald on record and negative impoliteness strategies are depended on.

5. Those annoyed hackers know what they are doing. They blackmail the companies legally since they study every step of threatening them. Their intention to cause them a detrimental action frightens them. The same two strategies are followed in this case.

6. No ambiguity is with the blackmailer's asking for such a huge amount of money otherwise he will expose some secrets which may cause the loss of his job. That is why the official fears and decides to pay for that blackmailer. Thus, bald on record and negative impoliteness are utilized in this case.

7. The officers were so direct and clear when they asked Stephen's son to give them $\$ 22.000$ otherwise he would be taken to prison. So, he was frightened because of what happened. Similarly, the first and third strategies of impoliteness are used.

8. Observing the Senior US Magistrate Judge when he was subjected to psychological warfare, the defendants intended to do that to stop him pursuing his legal claims. Such an obvious threat made the judge feel embarrassed and worried. So, bald on record and negative impoliteness are used.

9. In a prison, the two officers intended to make the prisoner hear them talking to each. If that defendant paid them an amount of money, they would drop the charge against him.

Such a damaged and intentional behaviour makes him feel frightened. He has to pay for them to leave the prison. Again, bald on record and negative impoliteness are utilized.

10. Mr. man's threatening local politicians and businessmen to expose sensitive information about them is intentional, direct and clear. Such a threat frightens such figures in the society. In the same way, the first and third strategies are utilized in this case. 


\section{Arabic Data: Analysis and Discussion}

Ten cases chosen are to be under an analysis according to an eclectic model. So, one by one case is to be analysed according to speech act theory first, implicature and then impoliteness.

\section{1. a. Background}

The plaintiff Alaa Atiya presented a complaint against the defendant, Khalid Falih because he threatened her to publish posts with voice messages on the Messenger among their relatives and neighbours or she forced her father to ask Khalid's father to work with him. Those posts and voice messages referred to her as a thief because of family problems.

\section{b. Speech Acts}

The two illocutionary verbs 'threaten and publish' affect the plaintiff negatively. She will be forced to do something rejected by her.

"Ask your father to make my father work with him otherwise I will publish posts and voice messages on the Messenger in which I tell all the neighbours and relatives you are a thief."

(xali ?abut3 yxali ?ubuy yshtiGal wayyah wa?illa ?anshir manashiir wbaSmat 9almasinchar ?aguul gidam ?ilaqarib wil?aSdiqaa? ?inti Haramiya.)

\section{2. a. Background}

Kamil, Suhaila's father refused the idea of marriage between Yasir and his daughter. On a day, Yasir came to Suhaila's father and told him that he would publish photos on the YouTube to expose a love relationship with his daughter.

\section{b. Speech Acts}

The illocutionary verb 'publish' will cause a scandal to the families.

- "I want to be frank with you. If you do not make me marry your daughter, I will publish photos of our love relationship on the YouTube."

- "What do you consider this? Is it a threat?"

- "Consider it in the way you like."

(shuuf 9emi ?akun SariiH wayak ?itha ma tzawichni bitak raH ?anshir Suwar 9alaqatna 9alyutyub.

shitsmih hatha tahdiid?

shitsamih samih.)

\section{3. a. Background}

Mustafa, a worker with a temporary contract in a Turkish company which fulfilled the Nasiriyah electricity station project, accused Thi-Qar electricity station manager of ending his contract. As a result, that worker threatened the manager to publish posts on the Face Book to show his relation with a lady in the station.

\section{b. Speech Acts}

The two illocutionary verbs 'threaten and publish' will damage his life: professional and family.

"You ended my contract. I should publish posts which expose your love relationship with the lady you know."

(?inta ?illi nihit 9aqdi lazim ?anshir manashiir tufDhaH 9alaqtak bilbnaya ?illi tu9rufha.)

\section{4. a. Background}

Luay from Basrah sent more than one message on the Face Book to a girl to make friendship with her. When she refused his request, he threatened her to harm her honour and reputation on the Face Book.

\section{b. Speech Acts}

'Threatening and harming' are used to expose her and this was dangerous for her as a lady.

- "I want to know who you are."

- "Who told you that I want to know who you are. Such a behaviour is shameful."

- "Why is it shameful? Anyway, if you do not be my friend, I will expose you and affect your honour and reputation negatively."

(?aHib ?at9arraf 


\section{Wminu galak ?ani ?aHib ?at9arraf. 9eb hay ?iltaSSarufat.}

lish 9eb. 9ala kulin ?itha ma tqibliin Sadaqty wallah ?afDhHit3wa?amiss bisharafit3 wasumu9tit3.)

\section{5. a. Background}

Udey, an official in an office, asked the manager to cancel the days of his absence because many absences would decrease his salary.

\section{b. Speech acts}

Udey threatened the manger to publish some photos to expose his son on the You Tube. Such an action would destroy the son and his father socially.

- "Sir, it is better for you and me to cancel my absences otherwise I will expose your son on the YouTube."

\section{(?ustath ?imsaH Giyabaty ?aHsan ?ilak w-ili wa?illa ?afDhaH ?ibnek 9alyutyub.)}

\section{6. a. Background}

Saleem, Suham's husband, wanted to marry another lady but his wife refused. So, he threatened her to publish a post on all the social media in which she has illegitimate relationships with men.

\section{b. Speech Acts}

By using the two illocutionary verbs 'threaten and publish' is to force her to accept his second marriage.

- "I will publish that you have sexual relationships with the men on the face Book and all the social media."

(hisa ?anshir bilfays w-kul wasa?il ?altawaSil w-?aguul ?inti tmarsiin ?alchins ma9a ?al?ashxaS w-?inti dayHa.)

\section{7. a. Background}

Fatin, the head at the department of promotions in an institute, was asked by Karrar, an official at the same place, to be promoted illegally. When she refused to fulfill his request, he threatened her to publish her family's birthday photos on the social media.

\section{b. Speech Acts}

Such a threat may cause a scandal to her family in such a Muslim community.

"If you do not promote me, I will expose you by publishing your family's birthday photos."

(?itha ma traqini ?afDhHich bnashir Siwar 9iid milad 9a?iltit3.)

\section{8. a. Background}

A party was held in a house among a group of girlfriends. One of those friends was a school manager's daughter, Ramla. The house owner's daughter, Sama was too lazy in the school.

\section{b. Speech Acts}

Sama's mother threatened the school manager to publish her daughter's personal photos and videos on the Face Book if she did not make her daughter pass the year.

In this case, there is a direct negative effect on the manager's professional life, reputation and future.

- "I do not want to hurt you, but if you do not accept to make my daughter pass this year, I will publish your daughter's photos and videos on the Face Book."

(?ana ma riid ?athiti3 bes tnachHiin binti wa?itha ma tirDhiin kal9ada ?anshir Siwar w-fidyuhat lbintit3 9alfays.)

\section{9. a. Background}

Ahmed was asked by a person, Jabir, to sell his house but Ahmed rejected. That person threatened Ahmed to publish a post in which he stole one of his relatives' money last year.

\section{b. Speech Acts}

Jabir wants to expose Ahmed as a thief to damage his reputation and life. All people whether in the house or his work, will disrespect him.

- "If you do not let me buy your house, I will say that you are a thief."

(tbi9ly ?ilbet lu ?aguul ?inta Haramy.) 


\section{0. a. Background}

Rasheed wanted to borrow some money from his brother's wife, Rasha but she refused.

\section{b. Speech Acts}

He began blackmailing her by telling her husband and all her relatives that she worked in a brothel. He had CDs that would be given to them as a scandal.

- "If you do not lend me money, I will expose you that you are working in the brothels and I have CDs to prove my speech."

\section{(tqarDhiny lu AfDhaH shuGlit3 bibyuut ?ilda9ara w-9indy sidiyat t?akid Hat3yii.)}

\section{c. Implicature}

In the blackmail cases, there is no implicature.

\section{d. Impoliteness}

1. With directness and clarity, Khalid asked Alaa to do something otherwise he would publish posts against her. She was really frightened because something bad would happen to her. In this case, two strategies are utilized, which are bald on record and negative impoliteness.

The use of (xely) to order someone to do something by force and threaten her of doing something dangerous and bad against her, expresses impoliteness.

2. Yasir expresses his hatred and malice directly towards Suhaila's father. Threatening him to expose their love relationship makes the father feel scared. Again, the first and third strategies of impoliteness are used.

Such a way of threatening and challenging an old man is impolite.

3. Direct hatred and aggression are clearly shown towards the station manager. After a clear threat, the manager is frightened because of what will happen. Similarly, bald on record and negative impoliteness are utilized. Threatening a man of exposing a relation with a lady who does not exist is impolite.

4. Such an unambiguous threat makes that lady feel scared, that is why, she presents a complaint against Luay. Like other cases, the same strategies are utilized.

Asking a girl to make a relationship with him otherwise he will expose her is impolite.

5. Udey tells the manager directly and frankly to cancel his absences otherwise his son will be in a dangerous situation in the community by publishing some shameful photos. This causes fear and worry for the father and his son. Thus, bald on record and negative impoliteness strategies are used. Such a behavious expresses impoliteness.

6. Showing his direct and clear hatred towards his wife reflectes the first strategy of impoliteness. Using an abusive word 'dayHa' refers to the positive impoliteness. Feeling frightened pushes her to sue her husband. This is the third strategy of impoliteness.

7. Karrar is so direct, clear without any ambiguity in his threatening Fatin to publish photos of her family birthday. Such exposure is a disaster to a lady among Arab people. Again, the first and third strategies of impoliteness are utilized. A husband becomes so dare to threaten his wife of saying that she is a lady who has illegitimate relations with men. How impolite he is !!!

8. Sama, as usual, failed in the exam. So, her mother intentionally kept Ramla's photos and videos to threaten her mother.

Such a threat forced the manager to make Sama pass the year illegally and this was a crime against the learning and teaching aspects. Forcing a manager to make a lazy student pass the year is impolite.

9. His direct hatred and malice to Ahmed reflect the first strategy of impoliteness. Jabir intends to do detrimental actions to Ahmed. Such a threat frightens Ahmed which indicates the third strategy of impoliteness.

Pressuring on a person to sell his house otherwise he will tell people that he is a thief even if it is a lie. This is really impoliteness.

10. This direct, clear and unambiguous threat to Rasha was because of money. He was so greedy and opportunist. Then, Rasha was so frightened because of that threat. Either lending him money or exposing her among her relatives and neighabours is impolite. 


\section{Conclusions}

There are a number of conclusions which are arrived at through this study. These conclusions are illustrated by the following general conclusions, similarities and differences in blackmail between English and Arabic:

\subsection{General Conclusions}

1. Blackmail is considered as a crime of opportunity and a crime of exploitation.

2. Blackmail as a speech act is expressed by utterances.

3. Some disclosed and discreditable information revealed will harm or embarrass the victim in a public way.

4. Cases of blackmail and extortion involve the exchange of money for information, favour, protection or silence.

5. In everyday communication, understanding any utterance relies on the conventional symbols used by speakers to communicate and our knowledge we have about speakers and the situation where an utterance is made. So, by knowledge, the speaker's intention to convey is to be revealed.

6. If there is no perlocutionary act, there is no verbal offence. The perlocutionary act is the characteristic feature of the verbal offence.

\subsection{Specific Conclusions}

These conclusions include a number of similarities and differences.

\subsubsection{Similarities}

1. Concerning the term 'pragmatics', there is a correspondence between English and Arabic. The Western scientists' efforts and the ancient Arabs' are complementary in terms of the study of pragmatics.

2. English and Arabic are similar to each other in terms of the legal language and its features.

3. English and Arabic agree on the locutionary, illocutionary, and perolcutionary acts. The same is with direct and indirect speech acts. But they are different from each other in terms of the way of classifying speech acts.

4. In English, blackmail is expressed by a limited number of illocutionary verbs which are ' threaten, publish, reveal, blackmail, tell, attack, post, expose, drop, disclose, had'. Similarly, in Arabic, blackmail is expressed by a limited number of illocutionary verbs which are 'threaten, publish, harm, expose, blackmail, tell'. Those verbs have the same perlocutionary effect which is the negative effect on the victim.

This refutes the hypothesis which is English and Arabic are different from each other in expressing strategies of blackmail in terms of speech act theory.

5. Blackmail a as speech act has both illocutionary and perlocutionary acts.

6. Most crimes like murder, robbery, blackmail, etc, are accompanied with a threat. Threatening people verbally, that is, uttering words or expressions, includes insults, abuses.

13. With blackmail, the same two strategies of impoliteness are applied which are negative impoliteness and bald on record in both languages.

This point refutes the hypothesis in which both languages are different from each other in blackmail in terms of impoliteness.

7. Blackmail is socially unacceptable in English and the Iraqi- Arabic communities.

8. There is no implicature in blackmail.

This point refutes the hypothesis in which English and Arabic are different from each other in blackmail in terms of implicature.

\subsection{Differences}

1. According to the Criminal Code for England by the Law Commission No. 177 (1989), blackmail is a crime with a punishable clause but in Iraq, although blackmail is a deliberate crime, there is no punishable clause to criminalize it in the Iraqi penal code.

2. After presenting the points of similarity and difference above, the research question of this study is answered.

\section{References}

Abu-Zaid, N. S. (2009). Pragmatics of Literary Discourse: Principles and Procedures. Satif: Wisdom House for Publishing and Distribution. 
Achiba, M. (2003). Learning to Request in a Second Language: A Study of Child Interlanguage Pragmatics. Sydney: Multilingual Matters LTD. https://doi.org/10.21832/9781853596131

Adrawy, Al- A'yashy (2011). Implicature in Tongue Pragmatics. Algeria: The Difference Publications.

Al- Abdullah, Mahmood Ibrahim (2013). Tribal Law between Functional law and Islam law. Baghdad: National Library.

Al- Ma'moury, Abdul-Wahab Abdullah A. (2006). Crimes of Kidnapping: A Comparative Legal Study with Islam Shari'a Rules. Al- Iskandariya: Modern University Bureau.

Al- Sharify, R. K. A., \& Zainab, A. M. A. (2017). Rules of the Oral Communication in the Meanings of the Holy Quran according to Al- Farra': A Pragmatic Study. Journal of the Basic Education College for Education and Human Sciences, 32, 420-442.

Algburi, B. Y. J., \& Igaab, Z. K. (2021). Defamation in English and Arabic: A Pragmatic Contrastive Study. International Linguistics Research, 4(2), 31-45. https://doi.org/10.30560/ilr.v4n2p31

Al-Seady, M. J. B. (1998a). Comparative Education: Some Basic Contributions of Islamic Education to Western Educational Thought. Al-Qadisiya Journal, 3(2), 82-89.

Al-Seady, M. J. B. (1998b). Teaching EFL Vocabulary. Al-Qadisiya Journal, 3(2), 59-69.

Al-Seady, M. J. B. (1998c). The Employment of English Lexicons by Adolescent Speakers of Nasiriya Iraqi Arabic as Determined by Sex Differentiation". Al-Qadisiya Journal, 3(2), 72-79.

Al-Seady, M. J. B. (2002a). English Phonetics. Nasiriya: Afaaq.

Al-Seady, M. J. B. (2002b). Some Morphological, Lexical and Syntactic Aspects of the Interlanguage of Third Year Students/ Dept. of English/College of Education/ University of Qadisiya. Journal of Qadisiya for Educational Sciences, 2(1), 13-19.

Al-Seady, M. J. B., \& Mohammed, K. A. A. (2002). Collocation in Three Texts of the Absurd: A Stylistic Comparative Cohesive Study. Journal of Al-Qadisiya for Educational Sciences, 3(2), 34-44.

Al-Sheikh, Z. K. (2006b). The Ability of Iraqi Undergraduates to Recognize and Produce Confusing Words in English. Journal of University of Thi-Qar, 2(3), 68-85.

Al-Sheikh, Z. K.(2006a). "Iraqi EFL Performance in using evidentiality". Journal of University of Thi-Qar, 2(3), 68-86.

Austin, J. L. (1962). How to Do Things with Words. Harvard: The President and Fellows of Harvard College.

Betti, M. J. (2007). Jokes in Iraq: A Study of coherence and Cohesion. In Journal of the College of Education. University of Wasit, 1(1), 399-411. https://doi.org/10.31185/eduj.Vol1.Iss1.694

Betti, M. J. and Hashim, T. G. (2018). The Lawyer's Discourse in the Courtroom: A Contrastive Study in English and Arabic. International Journal of English Linguistics, 8(3), 276-296. https://doi.org/10.5539/ijel.v8n3p276

Betti, M. J., \& Hasan, A. A.(2020). The Iraqi EFL Learners' Ability to Use Speech Acts in MA and Ph.D. Theses Defense. Education, Language and Sociology Research, 1(2), 41-65. https://doi.org/10.22158/elsr.v1n2p41

Betti, M. J., \& Hashim, Z. K. (2021). The Effect of Gender on the Bilingual and Bicultural Identity of the Iraqi EFL Learners' Recognition and Production of Request. International Linguistics Research, 4(3), 32-71. https://doi.org/10.30560/ilr.v4n3p32

Betti, M. J., \& Igaab, Z. K. (2018). A Contrastive Study of Modulation in English and Arabic. International Journal of English and Cultural Studies, 1(1), 30-45. https://doi.org/10.11114/ijecs.v1i1.3120

Betti, M. J., \& Mahdi, M. A. (2020). A Conversation Analysis of Repair Trouble Sources, Inadequacy and Positions in the Iraqi University Viva Discussions in English. International Linguistics Research, 3(4), 69-93. https://doi.org/10.30560/ilr.v3n4p69

Betti, M. J., \& Mahdi, M. A. (2021). A Conversation Analysis of Staff Members' and Researchers' Repair Strategies in the Iraqi University Viva Discussions in English. Education, Language and Sociology Research, 2(1), 14-56.

Betti, M. J., \& Noor, S. K. (2021). A Pragma-Stylistic Study of Implicature in Shakespeare's Hamlet and Twelfth Night. International Linguistics Research, 4(3), 12-31. https://doi.org/10.30560/ilr.v4n3p12

Betti, M. J., \& Yaseen, K. S. (2020). The Iraqi EFL Learners' Use of Conversational Maxims at the University 
Leve 1. Education, Language and Sociology Research, 1(1), 43-60. https://doi.org/10.22158/elsr.v1n1p43

Betti, M. J., Igaab, Z. K., \& Al-Ghizzi, M. T. H. (2018). The Iraqi EFL Learners' Use of Permission, Obligation and Prohibition. International Journal of English Linguistics, 8(3), 251-269. https://doi.org/10.5539/ijel.v8n3p251

Birner, B. J. (2013). Introduction to Pragmatics. London: Blackwell Publishing Ltd. https://doi.org/10.7202/1017210ar

Bolkhtot, M. (2018). The Manifestations of Implicature in Stories 'Jamila Znir' and 'Asabi Al-Itiham' as Models. In Intellectual Visions Journal. University of Souk Ahras, 107-133.

Boqra, N. (2009). General Linguistics: Its Directions and Present Issues. $1^{\text {st }}$ ed. Amman: Modern Books World.

Bousfield, D. (2008a). Impoliteness in the Struggle for Power. In Impoliteness in Language: Studies on its Interplay with Power in Theory and Practice. https://doi.org/10.1515/9783110208344

Bousfield, D. (2008b). Impoliteness in Interaction. Amsterdam: John Benjamins Publishing Company.

Collavin, Elena (2011). Speech Acts. In Foundations of Pragmatics. https://doi.org/10.1515/9783110214260.373

Culpeper, J. (1996). Towards an Anatomy of Impoliteness. In Journal of Pragmatics. 25, 349-367. https://doi.org/10.1016/0378-2166(95)00014-3

Culpeper, J. (2008). Reflections on Impoliteness, Relational Work and Power. In Impoliteness in language: Studies on its Interplay with Power in Theory and Practice.

Culpeper, J. (2011). Impoliteness: Using Language to Cause Offence. Cambridge: Cambridge University Press. https://doi.org/10.1017/CBO9780511975752

Culpeper, J. (2013). Impoliteness: Questions and Answers. In Aspects of Linguistic Impoliteness. https://doi.org/10.1075/hop.17.imp3

Davis, W. A. (2018). Calculability, Convention, and Conversational Implicature. In Beyond Semantics and Pragmatics. https://doi.org/10.1093/oso/9780198791492.003.0004

Dazhii, Dalkhosh Jarallah Hussein (2017). Speech Acts and their Applicative Models in the Holy Qur'an". Govary Tonza/ Zamarah/ Hawiny Journal, 249-303.

Dehham, S. H., Betti, M. J., \& Hussein, N. M. (2021). The Effect of Using Estafet Writing Technique to Enhance Students' Compositional Efficiency. Education, Language and Sociology Research, 2(1), 1-13.

Dripps, D. A. (2009). The Priority of Politics and Procedure over Perfectionism in Penal Law, or Blackmail in Perspective. In Crim Law and Philos, 3, 247-260. https://doi.org/10.1007/s11572-009-9072-y

Elliot, C., \& Frances, Q. (2004). Criminal Law. $5^{\text {th }}$ ed. London: Longman. https://doi.org/10.1350/jcla.68.3.253.34453

Fitzpatrick, D. (1998). The Philosophy of Blackmail. Indecent Offers or Coercive Proposals". In Journal of Social Philosophy, 29(1), 37-48. https://doi.org/10.1111/j.1467-9833.1998.tb00095.x

Geis, M. L. (1995). Speech Acts and Conversational Interaction. Cambridge: CUP. https://doi.org/10.1017/CBO9780511554452

Gharbiya, N. (2010). Pronunciations of Contracts in the Arabic Linguistic Heritage: A Pragmatic Structural Study. Unpublished MA Thesis. University of Mohammed Khaydhar Baskara: College of Arts and Languages.

Ginsburg, D., \& Paul, S. (2016). Blackmail: An Economic Analysis of the Law. In University of Pennsylvania Law Review, 141(5), 1849-1876. https://doi.org/10.2307/3312576

Grice, H. P. (1975). Logic and Conversation. Harvard: Harvard University Press.

Grundy, P. (2000). Doing Pragmatics. Oxford: OUP.

Hashim, A. M., \& Betti, M. J. (2020). Language Performance and Impairment of Iraqi Patients with Alzheimer's: A Case Study. Glossa, 3(8), 291-309.

Hussein, A. (2020). Linguistic Pragmatics: A Lecture. Al-Anbar University: College of Arts.

Igaab, Z. K. (2010). The Iraqi Undergraduates' Ability to Use and Find Correspondence between Lexical and Sentential Relations. University of Thi-Qar: College of Arts Journal.

Igaab, Z. K. (2010a). Reduplication in English and Arabic: A Contrastive Study. Journals Education for Girls, $1(1), 3-24$. 
Igaab, Z. K. (2010b). A Contrastive Study of Metathesis in English and Arabic. Wasit: Journal of College of Education, 1(7), 152-172.

Igaab, Z. K. (2015a). Apposition in English and Arabic: A Contrastive Study. University of Thi-Qar, College of Education for Humanities, 5(4), 110-143.

Igaab, Z. K. (2015b). Modification in English and Arabic: A Contrastive Study. Journal of University of Thi-Qar, College of Arts, 2(1), 1-23.

Igaab, Z. K., \& Al-Bdeary, D. R. T. (2016). Substitution in English and Arabic: A Contrastive Study. An Unpublished MA Thesis, College of Education, University of Thi-Qar.

Igaab, Z. K., \& Al-Manhalawey, M. S. O. (2010). Case in English and Arabic: A Contrastive Study. Journal of University of Thi-Qar, College of Arts, 1(1), 1-54.

Igaab, Z. K., \& Altai, S. M. M. (2018). Concord in English and Arabic: A Contrastive Study. International Journal of English Linguistics, 8(2), 288-297. https://doi.org/10.5539/ijel.v8n2p288

Igaab, Z. K., \& Israa, K. (2018). Affixation in English and Arabic: A Contrastive Study. English Language and Literature Studies, 8(1), 92-103. https://doi.org/10.5539/ells.v8n1p92

Igaab, Z. K., \& Tarrad, I. R. (2019). Pronouns in English and Arabic: A Contrastive Study. English Language and Literature Studies, 9(1), 53-69. https://doi.org/10.5539/ells.v9n1p53

Igaab, Zainab Kadim and Hanan Abdulhasan (2018). Collocation in English and Arabic: A Contrastive Study. English Language and Literature Studies, 8(4), 89-103. https://doi.org/10.5539/ells.v8n4p89

Ismail, S. (2005). Meaning Theory in Paul Grice's Philosophy. Cairo: Egyptian- Saudi House for Printing, Publishing and Distribution.

Juettner, B. (2009). Blackmail and Bribery. New York: GALE, Cengage Learning.

Juris, R. (1988). The Paradox of Blackmail. JOEL FEINBERG, 1(1), 83-95. https://doi.org/10.1111/j.14679337.1988.tb00006.x

Katz, L. (1996). ILL-Gotten Gains: Evasion, Blackmail, Fraud, and Kindred Puzzles of the Law. Chicago: The University of Chicago Press.

Khudhair, B. K. (2017). Imam Ali's Discourse Strategies: A Pragmatic Study/ Showing Responsibility. $1^{\text {st }}$ ed. Karbella: Institute of Nahj Al-Balagha Sciences.

Leech, G. (2014). The Pragmatics of Politeness. Oxford: OUP. https://doi.org/10.1093/acprof:oso/9780195341386.001.0001

Liedtke, F. (2011). The Impact of Literal Meaning on What - is- Said. In Experimental Pragmatics/ Semantics. https://doi.org/10.1075/la.175.03lie

Lindgren, J. (1984). Unraveling the Paradox of Blackmail. Columbia Law Review, 84, 670-717. https://doi.org/10.2307/1122502

Locher, M. A., \& Derek, B. (2008). Introduction: Impoliteness and Power in Language. Impoliteness in language: Studies on its Interplay with Power in Theory and Practice.

McAllister, P. G. (2015). Speech Acts: A Synchronic Perspective. Corpus Pragmatics: A Handbook.

Mey, J. L. (2004). Pragmatics: An Introduction. $2^{\text {nd }}$ ed. London: Blackwell Publishing. https://doi.org/10.1016/j.pragma.2004.04.001

Mustafa, M. M. (1964). Explaining Penal Code: The Private Section. $6^{\text {th }}$ ed. Cairo.

Peccei, J. S. (1999). Pragmatics Language Workbooks. London: Taylor and Francis Routledge. https://doi.org/10.4324/9780203255773

Proost, K. (2006). Speech Act Verbs. Concise Encyclopedia of Pragmatics. https://doi.org/10.1016/B0-08-0448542/01075-0

Ritchard, J. C., John, P., \& Haydy, P. (2007). $1^{\text {st }}$ ed. Longman Dictionary of Language Teaching \& Applied Linguistics: Emglish- English- Arabic. Longman: Egyptian International Publishing Co.

Rosenberg, B. E. (2008). Debate: Another Reason for Criminalizing Blackmail. The Journal of Political Philosophy, 16(3), 356-369. https://doi.org/10.1111/j.1467-9760.2008.00307.x

Rühlemann, C. (2019). Corpus Linguistics for Pragmatics: A Guide for Research. London: Routledge Taylor and 
Francis Group. https://doi.org/10.1007/s41701-018-0046-y

Sbisâ, M. (2016). Implicitness in Normative Texts. Pragmatics and Law: Practical and Theoretical Perspectives. https://doi.org/10.1007/978-3-319-44601-1_2

Searle, J. (1969). Speech Acts. The Philosophy of Language. Cambridge: CUP. https://doi.org/10.1017/CBO9781139173438

Searle, J. R. (1979). Expression and Meaning: Studies in the Theory of Speech Acts. Cambridge: CUP. https://doi.org/10.1017/CBO9780511609213

Shiya', H. B. (2016). Politeness: Its Principles, Rules and Strategies". In Journal of Humanities, 23(3), College of Education for Humanities.

Terkourafi, M. (2008). Toward a Unified Theory of Politeness, Impoliteness and Rudeness. Impoliteness in Language: Studies on its Interplay with Power in Theory and Practice.

Thomas, J. (1995). Meaning in Interaction: An Introduction to Pragmatics. London: Longman.

Ubaid, R. (1985). Crimes against Persons and Property. Arab Thinking House.

Wasik, M. (1990). Computer Crime: Computer and the Blackmail Threat. The Computer Law and Security Report. 4 CLSR. https://doi.org/10.1016/0267-3649(89)90132-5

Yousif, B. Z.(2020). Conversational Maxims in Pragmatics. Abhath Journal, 6(2), 110-124.

\section{Appendix (I).}

Table 1. A List of the Symbols of Arabic Phonemes (Betti, 2007: 409-410 with modifications added by the researcher)

\begin{tabular}{lll}
\hline Arabic Phonemes & Example & Meaning \\
? & ?ams & Yesterday \\
\hline b & bab & Door \\
t & timman & rice \\
th & tha9lab & fox \\
ch & chamaal & beauty \\
H & Hariim & women \\
x & xubuz & bread \\
d & tdanna & Be nearby. \\
D & Dabha & He threw it. \\
r & ramul & sand \\
z & zraar & button \\
s & suug & market \\
sh & shmaalak & What is wrong with you? \\
S & Sabur & patience \\
Dh & DhabuT & an officer \\
T & TamaTa & tomato \\
Dh & Dhaal & staying \\
9 & 9aali & High \\
G & Graab & crow \\
f & fiil & an elephant \\
q & qadiim & old \\
k & ka9ak & cake \\
l & limna & gather us. \\
m & maxadda & pillow \\
n & nibaH & Barked(The ( The dog barked. \\
h & hnaa & here \\
w & warana & behind us \\
j & yawm & day \\
g & ga9ad & He set down. \\
\hline & & \\
& &
\end{tabular}




\begin{tabular}{lll}
\hline $\mathrm{p}$ & parda & Curtain \\
$\mathrm{t3}$ & t3aali & bank of the river \\
i & mi9da & Stomach \\
a & saliim & healthy \\
u & ummii & My mother \\
ii & biina & in us \\
aa & saalim & Safe \\
uu & 9uud & stick \\
\hline
\end{tabular}

\section{Copyrights}

Copyright for this article is retained by the author(s), with first publication rights granted to the journal.

This is an open-access article distributed under the terms and conditions of the Creative Commons Attribution license (http://creativecommons.org/licenses/by/4.0/). 